\author{
Mariusz Maziarz \\ Wrocław University of Economics \\ Faculty of Economic Sciences \\ e-mail: mariusz.maziarz@ue.wroc.pl
}

\title{
Causality and inference in economics: An unended quest
}

\begin{abstract}
The aim of this article is to point to the unsolved research problems connected to causation in the philosophy of economics. First, the paper defines causation and discusses two notable approaches, i.e. the realist theory of causation and the instrumentalist theory of causation. Second, it offers a review the current research activity focusing on the problem of causation in economics. Third, it discusses several case studies. On the grounds of comparison of the research practice of economists and the current issues undertaken by the philosophers of economics, the paper concludes that there is a gap between the research practice and the normative methodological analyses and indicate the research questions that need to be addressed.
\end{abstract}

Keywords: causation, the philosophy of economics, recent research, causation in economics

JEL Classification: A19, B41

\footnotetext{
* The article is an updated version of the paper published in Polish in the Annales. Ethics in Economic Life, 20(1), 63-81. The research, the results of which are described in this article, were financed by the National Science Center (grant No. 2015/19/N/HS1/01066). The author would like to thank for the comments received from PhD Bartosz Scheuer and two anonymous reviewers of the Annales. Ethics in Economic Life journal. The author received a Ph.D. scholarship from the National Science Centre, Poland, under grant No. 2018/28/T/HS1/00007.
} 


\section{Introduction}

The goal of the article is to present the latest research on causality in the philosophy of economics, and a comparison of these with the research practice of economists and the formulation of research problems that have yet to be resolved. In the first part, an attempt is made to briefly present the concept of causal relation (ontology of causality) and answer the question of how it can be known (epistemology of causality). Causality is discussed in the light of the two popular paradigms of the philosophy of science: scientific realism and instrumentalism.

The second part of the article (in section 3) presents the results of the latest research on the problem of causality in the philosophy of economics. Next (in section 4), an analysis of selected case studies with the aim of presenting examples to support the thesis that there is a gap between the issues analyzed based on philosophy and methodology of economics, and the problems encountered by economists during research. The final section contains the conclusions from the comparison of the research practice of economists and problems related to the issues in ontology and epistemology of causality undertaken in the contemporary philosophy of economics. In addition, research problems have been formulated that have not yet been taken up in the literature on the subject, and their analysis from a methodological perspective seems necessary. First, the literature review of the subject brought to light the lack of methodological research devoted to the description of the methods used by the economists. Second, apart from the glorious exception of Granger causality tests, no research has been undertaken on philosophical assumptions concerning economic reality, and the nature of causal relationships that triggers the applied research methods and their grounding in the philosophical theories of causality. Third, the contemporary reflection by the philosophers of economics over the problems of ontology and epistemology of causality in modern economics has a limited possibility for economists to apply in research practice.

\section{Theoretical approaches to the problem of causality}

The term causal realism is used to refer to the view that cause-effect relationships exist in the world, outside the cognitive entity. Such an existence is well understood by one of the heroes of the stories written by Milne: when asked by Winnie the Pooh for the North Pole, Christopher Robin responds: "is just a thing that you discover" (Milne, 1988, p. 111; cf. Maziarz, 2013, pp. 27-38). Realists (causal) argue that a causal relation between $\mathrm{X}$ and $\mathrm{Y}$ exists if and only if there are causal mechanisms linking X to Y. Little (1991, p. 15) defines the concept of causal mechanism in social sciences as "a sequence of events, conditions, and processes 
leading from the explanans to the explanandum." Causal realism proposes that empirical evidence of causality be extended to the analysis of the mechanism of the postulated relation between cause and effect (Lewis-Beck, 2003, p. 100).

The second of the opposite ways of understanding the cause-effect relation is to identify the causal relation with regularity. Advocates of Hume's views, opposed to the view described above, believe that reality is not causal. The outside world simply "is" (Williamson, 2009). Therefore, causal relations are identified by them with empirical regularities, i.e. a correlation, model or causal graph.

It is worth noting that the following description of the theoretical approaches of causality certainly does not exhaust this wide subject. The philosophers and scientists have contemplated causality and causal relations from the very beginning of the philosophy itself (Beebee, 2009). Many definitions of the concept have been proposed throughout history but none has been widely accepted (Granger, 1980). Cartwright (2006), a philosopher of science at the London School of Economics, who points out that "each author of any definition argues that his definition is informative".

\subsection{The realistic approach}

The basic assumption of causal realism is to recognize that causality exists, in reality (Esfeld, 2011), and causal relations are not only an illusion noticed by the observer due to the temporal sequence of events, as Hume believed. Such an approach to the phenomenon of causality by causal realism means that it cannot be reduced to other manifestations of reality, such as the deterministic or probabilistic regularity of two phenomena.

Hence, causal realism presupposes the existence in the outside world of something that can be called a causal relation independent of the knowing mind. It is worth paying attention to the central role of causality in the reality that is the subject of research by scientists, which, for example, for Bhaskar (1997) was the essence of the studied phenomena. The second important feature of the causal relations, in accordance with the view presented here, is the existence of a certain type of necessity, e.g., the occurrence of A causes the occurrence of B (Chakravartty, 2014). This view has recently been eased due to the return of interest of science philosophers in exact sciences (such as physics, which operates on deterministic causal laws) to social sciences, where the issue of indeterminacy has been resolved by changing the way of understanding causal laws; these were found to be valid in the model and adding "ceteris paribus", meaning that the veracity of the sentence stating the existence of a causal relation held only when other factors remained unchanged. On the other hand, Cartwright (2006) advocated an understanding of causal laws as a tendency (capacity). For example, according to this interpretation, the law of demand expresses a tendency to decrease the need for the considered good when its price increases.

What is this necessity or inclination? Glennan points out that the answer to the above question is to indicate the mechanism, or system or process, which consists of many parts, i.e., reactions between the parts of the mechanism contributing 
to the stability and overlapping relations between the events analyzed. From his work on the analysis of philosophical research in causality relations, Glennan concluded, "discovering a mechanism is a gold standard for establishing and explaining causal connections" (Glennan, 2009).

According to Kistler (2006), the discovery of the universal dependence is insufficient to claim that the analyzed relation is causal. It results, among others from the fact that universal generalizations can be accidental. Therefore, Kistler argues that a full understanding of the law describing the mechanism of interaction between two phenomena (events) is necessary to state that the analyzed relation is causal.

In research practice, the discovery of the causative mechanism explaining the analyzed phenomenon is reduced to the analysis of lower levels of reality (Hardt, 2013), i.e. theories describing more specific issues. For example, learning about the theory of gravity, or the mechanism of interaction between two bodies, allows us one to recognize that the attraction process is causative, and is not so-called, pseudo-process, as in the case of the shifting shadow of a tree during the day (Kistler, 2006).

In summary, the study of causal phenomena in light of a realistic approach can be equated with the analysis of the interaction between two processes. In the case when the analyzed relation can be described by laws due to the recognition of mechanisms linking events $\mathrm{A}$ and $\mathrm{B}$, it can be assumed that the relation is causal.

\subsection{The instrumentalist approach}

Other philosophers strongly opposed the real existence of causal relations. Many philosophers and scientists during the period when logical positivism was the most respected philosophy of science, professed the views expressed later by Bertrand Russell, who recognized causality as a relic of a past era that survived, like the monarchy, solely because it did no harm (Chakravartty, 2014).

One of the most famous sceptics was David Hume. This eighteenth-century historian, who also dealt with the philosophy and methodology of social sciences, believed that the human mind was incapable of knowing the causal relation. Instead of observing such a relation, you can only see event A and the following event B. Hume (1739) justified his view by the fact that an observer can experience only one phenomenon at a given time. Since the relation between cause and effect connects two moments on the time continuum, it is impossible to get to know directly.

Hoover (2006) illustrates the analysis carried out by Hume as an example of a game of billiards: the ball $\mathrm{A}$ hits the ball $\mathrm{B}$ and causes it to move. What conclusions does the eighteenth-century historian and philosopher draw from observing such an event? First, causality is asymmetrical, which means that if A causes B, B does not cause A. From this premise, Hume deduced that the effect must precede the cause in time. Secondly, he believed that the causes were effective, which 
meant that one should make a distinction between accidental correlation and causal relationship, the feature of which is that the first element of the relationship produces the effect.

Hume's scepticism was reflected in the view that a permanent relationship between cause and effect cannot be understood in any other way than by induction based on observing events in a temporal order. Therefore, Hume thought that talking about causes was a habit of the mind rather than a reasonably logical phenomenon.

Despite the popularization of his views, many classical economists have sought to analyze economic phenomena in terms of causes and effects. The most important were Ricardo and Mill (Maziarz, 2015). Mill (1966) proposed five methods of inference of causal relations from data: (i) agreement, (ii) difference, (iii) joint (or double) method of agreement and difference, (iv) residues and, (v) concomitant variations.

The method of difference allows to determine the cause of the investigated phenomenon when the observer must deal with two situations: in the first case, a certain effect occurred, in the second case-it did not. If these situations are similar in all aspects except one factor, this factor is considered the cause of the phenomenon.

Despite the existence of various ways of studying causality in the history of economics, modern econometrics urge the classical philosophers to justify their methods. Granger (2012), basing his argument on Hume's deliberations, asserted that it was possible to draw conclusions and formulate the conditions that a relation must fulfil to deserve the name causal. Granger's causality is characterized by two features:

(1) the cause happens prior to its effect,

(2) the cause has unique information about the future values of its effect.

Considering the tradition of the reductionist approach to causality, which is equated with a permanent relationship and time sequence, Wiener (1956) proposed the first definition of causality that may be used to develop methods for the quantitative evaluation of the occurrence of such a relationship:

For two simultaneously measured signals, if we can predict the first signal better by using the past information from the second one than by using the information without it, then we call the second signal causal to the first one.

On this basis, Granger (1980) proposed a definition of causality with three axioms. First, the past and the present may cause the future, but the reverse dependence is impossible. Second, the set of all relevant information $\left(\Omega_{n}\right)$ does not contain unnecessary information, i.e. in the case when some variables $\left(Z_{n}\right)$ are deterministically correlated with each other, they should be excluded from ' $\Omega_{\mathrm{n}}$. Third, all causal relationships remain constant over time. On this basis, Granger developed his own definition of causality, which is presented below. To be able to apply it in the process of econometric testing in the analysis of the time series, a simplifying assumption should be made that ' $\Omega_{t}$ only contains the relevant variables: 


$$
\begin{gathered}
Y_{n} \text { causes } X_{n+1} \text { if and only if: } \\
P\left(\left.X_{n+1} \in A\right|^{\prime} \Omega_{n}\right) \neq P\left(\left.X_{n+1} \in A\right|^{\prime} \Omega_{n}-Y_{n}\right) \text { for A }
\end{gathered}
$$

$X_{t}, Y_{t}$ - variables suspected of being a cause and an effect

' $\Omega_{t}$ - the information available as of time $t$ in the entire universe.

It should be emphasized that Granger's causality tests are the only ones whose philosophical inspirations and assumptions have been investigated. The next section covers the areas of the latest research in economic philosophy devoted to the problem of causation, a comparison of selected economic research, and identification of the unresolved research problems.

\section{Research on causality in contemporary philosophy of economics}

Based on the literature review, it can be concluded that in the contemporary methodology of economics, there is a lack of descriptive approaches to the methods used by economists to justify conclusions regarding the existence of causal relations in the economic reality. So far, no one has inquired what philosophical concepts and assumptions are at the basis of these methods. One exception is the statistical Granger causality tests $(1969,1980)$. Nor has there been any systematic study of the methodology currently used by economists to answer the questions raised here earlier. Other disciplines such as physics, chemistry, and biology that engage in the analysis of causality have been more pursuant. For example, Shadish, Cook and Campbell (2002) presented the theory of cause generalization grounded in the methodological analysis of activities undertaken by researchers in those areas of science. Woodward (2003), using case studies from the social sciences and a review of the methodological literature, stated that causation was understood by social researchers as an unchanged relation in the case of intervention.

Methodologists and economics philosophers have primarily focused on the historical development of understanding causality and methods devoted to its cognition used by economists and their normative investigations that are not closely related to the research practice of economists. Consequently, no theoretical framework for conducting fruitful economic studies or formulating appropriate recommendations for economic politicians have evolved.

Writings aimed at presenting a review of the methods of understanding the causal relations used by economists, focus on the analysis of the views of philosophers of economics, presenting the historical outline and discussing selected contemporary methods that are not widely used. For example, LeRoy (2004) emphasizes the essence of the graph-theoretical approach, without discussing the current research practice of economists. Hoover presents historical development and philosophical justification of selected historical theoretical and econometric methods, discussing, among others, research of the Cowles Commission and understanding of causality by Herbert Simon (Hoover, 2006). Monographic studies analyzing the 
epistemology of the causality of a chosen economist or one school of economic thought are also popular. An example of this is the work of Hammond (2005), who analyzed the understanding of the concept of causality and methodology used by Milton Friedman, the creator of monetarism. Likewise, Blaug (1992) devoted to the understanding of causality by John Stuart Mill and other philosophers of the $18^{\text {th }}$ and $19^{\text {th }}$ centuries.

For normative analyzes, one can include, famous among methodologists of economics, Cartwright's work (2007a), which made a philosophical analysis of ontology and epistemology of causality and argued that investigations of causal relation were possible not only by means of randomized controlled trials but also by other hypothetical-deductive methods, e.g., econometric models for measuring the average impact of an intervention on a dependent variable. Cartwright suggested that the choice of a method should be determined by the scope and type of knowledge about the analyzed phenomenon (2007a). Pearl (2009) presented and unified four philosophical approaches to causation the probabilistic, manipulative, counterfactual, and structural, and devises such as simple mathematical tools for studying the relationships between causal connections in the studied phenomena. Hoover (2001) dealt with the problem of causality in macroeconomics, but he analyzed not the practice of economists, but methodological research devoted to this problem. The exceptions to the above systematization of methodological research on understanding and causation in economics are articles devoted to these issues in behavioural economics (for example: Loewenstein, 1999), although the normative approach is also dominant on this ground, i.e. the formulation of recommendations for increasing the role of experiments in the methodology of economics (for example, Harrison \& List, 2004).

Over the past few years there has been a significant increase in interest in the causality problem, as evidenced by the increase in the number of articles appearing in the important journals devoted to the problems of the philosophy of economics (among others "Economics and Philosophy", "Journal of Economic Methodology", "Economics, Politics", "Philosophy and Economics"). However, most of the recent writings are normative examinations offering few applications to the research practice of economists. Grüne-Yanoff (2015), not unlike many philosophers of economics, takes a realist stand and argues that the justification for the decision to undertake economic intervention is appropriate only when it refers to causal mechanisms. LeRoy's investigations (2015) also belong to the trend of normative approaches to the problem of causality in the methodology of economics. He considered the features a theoretical model must have to allow for the deductive cognition of unchanging relationships under the influence of intervention (implementation-neutral causation). Cleveau and Mireles-Flores (2014) deserve credit for their efforts in the research on the epistemology of causality of the recent years, and their attempt to address the question of understanding the concept of causality by economists based on a methodological analysis of the OECD study (1994) on the causes of unemployment. Cleveau and Mireles-Flores (2014) state that economists rarely express explicitly which philosophical causation theory they consider to be true and present a point of view that the question about the adequacy of, among others, regularity theory, probabilistic theory, counterfactual theory, process theory, or manipulation theory remains open. 


\section{Research practice of economists}

The need to conduct research on the epistemology of causality in modern economic research is emphasized by the observation of economists' practice and the lack thereof in the current philosophy of economics. First, methodological pluralism can be observed in contemporary economic research. Economics has failed to developed a uniform methodology, and competitive schools of thought (research paradigms) contribute to situations where, on the basis of the same empirical data, economists come to different conclusions about the direction or existence of causation, e.g., contradicting results of research on the relationship between the monetary base and economic growth or the threshold hypothesis (Stock \& Watson, 1989; Maziarz, 2017). Second, the analysis of economists' research practice indicates that it draws causal conclusions on the basis of premises unjustified from the perspective of modern philosophy of economics.

There are frequent cases of making conclusions about the causal nature of a relationship based on observations of precedence over time, correlations or differences in mean values in different subgroups of the studied population. Two case studies based on high-profile articles in recent years will be discussed below. The authors of these articles, basing on their econometric observations arrived at opposing conclusions. It is worth emphasizing that the results of the research have been used to justify the economic policy conducted by the governments that allows presuming that they have been interpreted in terms of causality. The use of the research discussed below to make decisions on economic policy confirms Woodward's observation that scientists interested in social sciences treat instrumentalist causality, naming such permanent relationships despite interventions (Woodward, 2003).

The first case study will be based on the Reinhart-Rogoff (2010) case, which is misunderstood by previous commentators. Namely, this is not an error highlighted by Herndon, Ash and Pollin (2014), but the different research methods used by Reinhart and Rogoff (2010) lead to different results (compare point 4.1). The second case study will be based on research on the truth of the expansionary fiscal contraction hypothesis, where, as in the previous case, Guajardo, Leigh \& Pescatori (2010), and Alesina \& Ardagna (2009) reached different conclusions.

In addition, the analysis of economists' research practice indicates that there are cases when they apply methodology grounded in the philosophy of economics in a manner not recommended by methodologists. An example of such a situation may be the Madrak-Grochowska and Żurek (2011) research, which used Granger's causality tests to analyze the relationship between the time series of variation of returns on selected stock market indices, i.e. to study a phenomenon that, according to current theoretical knowledge, is not causative. It is worth noting that the author of the method objected to such application of the causality test, arguing that this may lead to incorrect conclusions (Granger, 1969). Furthermore, practising economists often focus on one of the methods (theoretical deduction or 
econometric analysis of correlations) resulting from the two main philosophical approaches to the problem of causality, which can also lead to wrong conclusions (Maziarz, 2015).

\subsection{The Reinhart-Rogoff affair}

The so-called Reinhart-Rogoff affair is a term applied to the discussion caused by the publication of two high-profile and influential articles. Reinhart and Rogoff (2010), on the basis of their historic database containing some 3000 observations of the level of public debt to GDP ratio for 44 countries over nearly 200 years, presented results indicating the existence of a threshold in the relationship between the said indicator and the economic development rate. According to the threshold hypothesis formulated in the article, Growth in a Time of Debt (2010), public debt exceeding $90 \%$ of the public debt-to-GDP ratio significantly slowed economic growth.

Their article was criticized by Herndon, Ash and Pollin (2014), who, after unsuccessful attempts to replicate and receive a spreadsheet used by Reinhart and Rogoff to perform calculations, indicated three errors: (1) the wrong formula in the spreadsheet (which omitted the first five countries in alphabetical order), (2) way of counting the average and (3) not including a time series representing New Zealand data in the database.

It is worth noting that the only mistake is the incorrect specification of the formula adding up the cells in a spreadsheet, which led to the omission of the average economic development of Australia, Austria, Belgium, Canada and Denmark. The error did not significantly affect the estimated average values (differences between 0.1 and 0.3 percentage points were noted). The other two errors pointed out by Herndon, Ash and Pollin rather deserve the name of different methodological choices, because there are arguments justifying the non-inclusion of the New Zealand debt time series and the weighted average use by Reinhart and Rogoff (2010). ${ }^{1}$ Considering the impact of alternative methodological choices on estimating the economic growth rate in four groups of countries / years separated due to the variation in the value of the public debt to GDP ratio, which is much larger than the role of the above-mentioned error (see Table 1), it can be concluded that - contrary to the previous comments present in the literature on the subject - the differences in results obtained by Reinhart \& Rogoff (2010), and Herndon, Ash \& Pollin (2014) are not a result of an error but due to different methodological choices.

\footnotetext{
${ }^{1}$ The autocorrelation and the phenomenon of debt overhangs, indicated in the literature on the subject, cause that using an unweighted arithmetic mean could lead to misleading results (Dafermos, 2015; Reinhart, Reinhart \& Rogoff, 2012; cf. Maziarz, 2018).
} 
Table 1. Average growth rates published by Reinhart and Rogoff (2010) and values obtained by Herndon, Ash and Pollin (2014) during the replication of their study

\begin{tabular}{lcccc}
\hline & \multicolumn{4}{c}{ Category: public debt to GDP } \\
Method & $<30 \%$ & $30 \%-60 \%$ & $60 \%-90 \%$ & $>90 \%$ \\
\hline $\begin{array}{l}\text { Results corrected by } \\
\text { Herndon, Ash and Pollin }\end{array}$ & 4.1 & 3.1 & 3.2 & 2.2 \\
\hline Elements of replication & & & & \\
\hline$\quad$ Error in the spreadsheet & 4.0 & 3.0 & 3.2 & 1.9 \\
$\quad$ A selective choice of years & 4.2 & 3.1 & 3.2 & 1.9 \\
$\quad$ Weighted average & 4.0 & 3.0 & 3.0 & 1.9 \\
\hline $\begin{array}{l}\text { Results published by } \\
\text { Reinhart and Rogoff }\end{array}$ & 4.1 & 2.8 & 2.8 & -0.1 \\
\hline
\end{tabular}

Note. Adapted from "Does high public debt consistently stifle economic growth? A critique of Reinhart and Rogoff," by Th. Herndon, M. Ash \& R. Pollin, 2014, Cambridge Journal of Economics, 38(2), 257-279.

Although Reinhart and Rogoff (2010) formulating the hypothesis that "high debt/GDP levels (90 per cent and above) are associated with notably lower growth outcomes" they did not claim that their discovery is of a causal nature, but the $90 \%$ threshold hypothesis was interpreted in this way by many academic economists and economic politicians. The article Growth in a Time of Debt has been named by Krugman (2013), one of the most important economic analyzes of recent years. The results obtained by Reinhart and Rogoff deserved such a title thanks to the fact that their publications appeared during the financial crisis when issues of public debt size and its impact on economic growth gained importance in conjunction with the increased indebtedness of many countries due to the necessity to finance rescue plans for bankrupt banks. The article has been cited in the US Republican budget and by Oli Rehn, European Commissioner for the Economy of the European Union. In addition, it was appealed to by many politicians, including Manuel Barroso, Angela Merkel and Wolfgang Schaube (Botsch, 2013; Smith, 2013).

\subsection{Research on the hypothesis of the expansionary fiscal contraction}

Considering the current opinion among some economists about the need to reduce the size of the public debt in many countries of the world, which, in response to the financial crisis, decided to implement stimulus packages financed by bond sales, the question is: when should budget cuts be made? The cliometry experts, who are investigating the expansionary fiscal contraction hypothesis, try to answer the question-is it better for the average pace of economic development to immediately limit public debt, or is it more fruitful to wait until the country leaves the recession? The hypothesis was formulated nearly three decades ago, but the question of whether budget cuts have a positive impact on the pace of economic development and in the short term, remains unanswered.

As in the case of the contrasting results obtained in the two aforementioned studies, the opinions of economists about the short-term impact of budget cuts on economic growth are divided. Keynesians, believing in stable prices and wages in 
the short term, argue that budget cuts contribute to a short-term recession (or a slowdown) resulting in a drop in aggregate demand. On the other hand, neoclassical economists argue that reducing the deficit may have a positive impact on the pace of economic development even in the short term, due to the increase of the wealth of consumers (by reducing tax rates and the risk premium) and reduction of wages that positively affects competitiveness (Alesina \& Perotti, 1996).

Due to the alternative theoretical approaches, the research on the expansionary fiscal contraction hypothesis has focused on the cliometrics analysis of the impact of reducing the deficit on economic growth in the past. The first step in such an analysis is to indicate the years when individual countries made budget cuts. Guajardo, Leigh and Pescatori (2010) decided to conduct their analysis based on the methodology developed by Romer and Romer (2007), who, in turn, based their research on fiscal shocks on the analysis of descriptive sources. Guajardo, Leigh and Pescatori (2010), using an action-based approach, analyzed OECD Economic Surveys, IMF Staff Reports, IMF Recent Economic Developments and other reports and government documents related to budget policy. Since econometric analysis of changes in the pace of economic development in the years following the budget-cuts identified, they concluded that the hypothesis of expansionary fiscal contraction is not supportable.

Alesina and Ardagna (2009) analyzed the years in which the cuts were made and changes in the volume of cyclically adjusted primary balance (CAPB) to indicate Cliometrics experts used the correction method developed by Blanchard (1990). After identifying the years when the adjusted budget deficit decreased by more than $1.5 \%$ of GDP and analyzing changes in GDP in subsequent years, economists have concluded that the hypothesis of expansionary fiscal contraction is valid.

The contradiction of the conclusions discussed above results from the use of different methods identifying the moments of budget cuts. An analysis of the years indicated in both articles shows that only $30 \%$ of budget cuts were identified by both methods at the same time (see Table 2). Both methodologies are widely used and supported by their followers making it difficult to choose one over the other (2018).

The second similarity in these two studies is that economists, formulate their recommendations for economic policy on the analysis of historical relationships between time series. The article by Guajardo, Leigh and Pescatori (2010) was published in the report of the International Monetary Fund-World Economic Outlook, devoted to the current macroeconomic situation and ways to counteract the crisis. Authors explicitly support the recommendations formulated at the end of the article by Alesina and Ardagna, who advised the immediate reduction of the size of the budget deficit and public debt. On the other hand, Guajardo, Leigh and Pescatori using the cliometric observations recommended economic policies to refrain from budget reforms until the economies leave the recession. 
Table 2. Comparison of years indicated as periods of budget cuts in selected countries.

\begin{tabular}{|c|c|c|}
\hline Country & Guajardo, Leigh \& Pescatori (2010) & Alesina \& Ardagna (2009) \\
\hline Australia & $1986 ; 1987$ & $1987 ; 1988$ \\
\hline Austria & & 1984; 1996; 1997; 2005 \\
\hline Belgium & $1982 ; 1983 ; 1987 ; 1993$ & $1982 ; 1984 ; 1987 ; 2006$ \\
\hline Denmark & $1983 ; 1984 ; 1985 ; 1986$ & $1983 ; 1984 ; 1985 ; 1986 ; 2005$ \\
\hline Finland & 1992; 1993; 1994; 1996; 1997; 1998 & $1981 ; 1984 ; 1988 ; 1994 ; 1996 ; 1998 ; 2000$ \\
\hline France & & 1996 \\
\hline Greece & & 1986; 1991; 1994; 1996; 2005; 2006 \\
\hline Spain & & $1986 ; 1987 ; 1994 ; 1996$ \\
\hline Netherlands & & $1983 ; 1988 ; 1991 ; 1993 ; 1996$ \\
\hline Ireland & $1982 ; 1983 ; 1987 ; 1988 ; 2009$ & $1984 ; 1987 ; 1988 ; 1989 ; 2000$ \\
\hline Japan & 1997 & $1984 ; 1999 ; 2001 ; 2006$ \\
\hline Canada & & 1981; 1986; 1987; 1995; 1996; 1997 \\
\hline Germany & 1997 & $1996 ; 2000$ \\
\hline Norway & & 1980; 1983; 1989; 1996; 2000; 2004; 2005 \\
\hline New Zeland & & $1987 ; 1989 ; 1993 ; 1994 ; 2000$ \\
\hline Portugal & $1983 ; 2002$ & $\begin{array}{l}\text { 1982; 1983; 1986; 1988; 1992; 1995; } \\
\text { 2002; } 2006\end{array}$ \\
\hline $\begin{array}{l}\text { United } \\
\text { States }\end{array}$ & 1991 & \\
\hline Sweden & 1983; 1993; 1995; 1996; 1997 & $\begin{array}{l}\text { 1981; 1983; 1984; 1986; 1987; 1994; } \\
\text { 1996; 1997; } 2004\end{array}$ \\
\hline $\begin{array}{l}\text { Great } \\
\text { Britain }\end{array}$ & $1981 ; 1997$ & 1982; 1988; 1996; 1997; 1998; 2000 \\
\hline Italy & 1992; 1993; 1995; 1997 & 1980; 1982; 1990; 1991; 1992; 1997; 2007 \\
\hline
\end{tabular}

\section{Conclusions}

The discrepancy between the philosophy of economics and the research practice of economists is particularly strong in the field of ontology and epistemology of causality and causal relations in the economy. The case studies discussed above show that economists make recommendations for economic politicians, i.e. they state the existence of causal relationships based on premises which-according to the contemporary philosophy of economics - are unjustifiable. On the other hand, modern philosophers who specialize in issues related to economics and social sciences and methodologists seem to draw normative conclusions that, due to their restrictiveness, cannot be observed while conducting research by economists.

McCloskey (1998) strongly opposed the formulation rules limiting the freedom and ingenuity of scientists on the basis of methodological research. However, McCloskey recommended that the philosophers of science dealing with descrip- 
tive analyzes of research practice and ways of justifying their results, and the discrepancy between the aforementioned studies on causality in the philosophy of economics and the methods of inference of causal relations by economists in the case studies discussed, it is possible to formulate research problems that have not yet been undertaken and analyzed exhaustively:

(1) What research methods contemporary economists use to infer causal relations?

(2) What philosophical assumptions are based on these methods?

(3) Which of the philosophical theories of causality reflect the understanding of this term by economists?

(4) Which of the paradigms of the philosophy of science best describes the activities of economists?

The solution to the above research problems through systematic research on the scientific practice of economists will allow us to understand the methods of investigating causal relationships used in research and their limitations. In addition, by applying - for example - the approach of reference semantics, i.e. attempting to answer the question what features an economic reality would have had, what causal relations would have to be, that the methods used by economists would be appropriate, it would be possible to formulate conclusions on the ways of understanding causality by economists and an indication of these paradigms of philosophy of science and philosophical theories of causality that offer the greatest descriptive adequacy.

\section{References}

Alesina, A., \& Ardagna, S. (2009). Large changes in fiscal policy: Taxes versus spending. NBER Working Papers, No. 15438.

Alesina, A., \& Perotti, R. (1996). Fiscal adjustments in OECD countries: Composition and macroeconomic effects. NBER Working Paper, No. 5730.

Beebee, H. (2009). Introduction. In H. Beebee, Ch. Hitchcock, \& P. Menzies (Eds.), The Oxford handbook of causation. London: Oxford University Press.

Bhaskar, R. (1997). A realist theory of science. London: Verso.

Blanchard, O. (1990). Suggestions for a new set of fiscal indicators. OECD Economics Department Working Papers, 79.

Blaug, M. (1992). The methodology of economics. Or how economists explain. Cambridge University Press.

Botsch, A. (2013). Hypocritical versus hippocratic economics. In Th. Palley \& G. Horn (Ed.), Restoring shared prosperity. A policy agenda from leading Keynesian economists. Dusseldorf: Boeckler.

Cartwright, N. (1989). Nature's capacities and their measurement. Oxford University Press.

Cartwright, N. (2006). Where is the theory in our „Theories” of Causality? Journal of Philosophy, 103(2), 55-66.

Cartwright, N. (2007a). Are RCTs the gold standard? BioSocieties, 2, 11-20. 
Cartwright, N. (2007b). Hunting causes and using them: Approaches in philosophy and economics. Cambridge University Press.

Chakravartty, A. (2014). Causal realism: Events and processes. Erkenntnis, 63, 7-31.

Claveau, F., \& Mireles-Flores, L. (2014). On the meaning of causal generalisations in policy-oriented economic research. International Studies in the Philosophy of Science, 28(4), 397-416.

Dafermos, Y. (2015). The 'other half' of the public debt-economic growth relationship: A note on Reinhart and Rogoff. European Journal of Economics and Economic Policies: Intervention, 12(1), 20-28.

Esfeld, M. (2011). Causal realism. In H. Beebee, Ch. Hitchcock, \& P. Menzies (Eds.), The Oxford Handbook of Causation. Oxford University Press.

Glennan, S. (2009). Mechanisms. In H. Beebee, Ch. Hitchcock, \& P. Menzies (Eds.), The Oxford Handbook of Causation. Oxford University Press.

Granger, C. W. J. (1969). Investigating causal relations by econometric models and crossspectral methods. Econometrica, 37(3), 424-438.

Granger, C. W. J. (1980). Testing for causality. A personal viewpoint. Journal of Economic Dynamic and Control, 2(4), 329-352.

Granger, C. W. J. (2012). Forecasting. In U. Mäki (Ed.), Philosophy of economics. Helsinki: Elsevier.

Grüne-Yanoff, T. (2015). Why behavioral policy needs mechanistic evidence. Economics and Philosophy, 32(3), 1-21.

Guajardo, J., Leigh, D., \& Pescatori, A. (2010). Will it hurt? Macroeconomic effects of fiscal policy: evidence from industrial and developing countries. In World Economic Outlook (pp. 93-124). International Monetary Fund.

Hammond, D. (2005). Theory and measurement: Causality issues in Milton Friedman's monetary economics. Cambridge University Press.

Hardt, Ł. (2013). Studia z realistycznej filozofii ekonomii. Warsaw: C.H. Beck.

Harrison, G., \& List, J. (2004). Field experiments. Journal of Economic Literature, 12(1), $1009-1055$.

Herndon, Th., Ash, M., \& Pollin, R. (2014). Does high public debt consistently stifle economic growth? A critique of Reinhart and Rogoff. Cambridge Journal of Economics, 38(2), 257-279.

Hoover, K. (2001). Causality in macroeconomics. Cambridge University Press.

Hoover, K. (2006). Causality in economics and econometrics. In New Palgrave Dictionary of Economics. London: Palgrave.

Kistler, M. (2006). Causation and laws of nature. London: Routledge.

Krugman, P. (2013). How the case for austerity has crumbled. New York Review of Books, 6 .

LeRoy, S. (2004). Causality in economics. LSE Centre for Philosophy of Natural and Social Science, Technical Report 20/04 ["Causality: Metaphysics and Methods"].

LeRoy, S. (2015). Implementation-neutral causation. Economics and Philosophy, 32(1), 121-142. doi: 10.1017/S0266267115000280

Lewis-Beck, M. (2003). The SAGE Encyclopaedia of Social Science Research Methods. Washington: SAGE. 
Little, D. (1991). Varieties of social explanation: An introduction to the philosophy of social science. Colorado: Westview Press, Boulder.

Loewenstein, G. (1999). Experimental Economics from the vantage-point of behavioural economics. Economic Journal, 109(453), 25-34.

Madrak-Grochowska, M., \& Żurek, M. (2011). Testing for causality in variance. Oeconomia Copernicana, 2(4), 5-25.

Maziarz, M. (2013). Spór o obiektywne istnienie obiektów teorii ekonomicznych. Argument na rzecz esencjalizmu. Przeglad Prawniczy, Ekonomiczny i Społeczny, 4, 27-38.

Maziarz, M. (2015a). O wartości informacyjnej testów przyczynowości w sensie Grangera. Optimum. Studia Ekonomiczne, 74(2), 152-170.

Maziarz, M. (2015b). Sposoby poznania relacji przyczynowych w ekonomii. Argument na rzecz sceptycyzmu. Kwartalnik Prawo-Społeczeństwo-Ekonomia, 2, 59-81.

Maziarz, M. (2017a). Przyczynowość w ekonomii. Najnowsze badania i nierozwiązane problemy. Annales. Ethics in Economic Life, 20(1), 63-81.

Maziarz, M. (2017b). The Reinhart-Rogoff controversy as an instance of 'emerging contrary result' phenomenon. Journal of Economic Methodology, 24(3), 213-225.

Maziarz, M. (2019). It's all in the eye of beholder. Argumenta Oeconomica (Manuscript accepted for publication).

McCloskey, D. (1998). Rhetoric of economics. University of Wisconsin Press.

Mill, J. S. (1966). Principles of political economy (E. Taylor, Trans.). Warsaw: Polskie Wydawnictwo Naukowe.

Milne, A. (1988). Winnie the Pooh. Warsaw: Nasza Księgarnia.

OECD. (1994). Jobs study: Evidence and explanations. Paris: OECD Publishing.

Pearl, J. (2009). Causality: Models, reasoning and inference. Cambridge University Press.

Reinhart, C., \& Rogoff, K. (2010). Growth in a time of debt. American Economic Review, 100(2), 573-578.

Reinhart, C., Reinhart, V., \& Rogoff, K. (2012). Debt overhangs: Past and present. NBER Working Paper, No. 18015.

Romer, Ch., \& Romer, D. (2007). The macroeconomic effects of tax changes: Estimates based on a new measure of fiscal shocks. NBER Working Papers, No. 13264.

Shadish, W., Cook, Th., \& Campbell, Th. (2002). Experimental and quasi-experimental designs for generalized causal inference. Levland: Wadsworth Cengage Learning.

Smith, J. (2013, April 20). From Reinhart \& Rogoff's own data: UK GDP increased pace of economic growth when debt-to-GDP ratio was highest - and the debt ratio came down. Prime Economics. http://www.primeeco-nomics.org/articles/1785

Stock, J., \& Watson, M. (1989). Interpreting the evidence on money-income causality, Journal of Econometrics, 40(1), 161-181.

Wiener, M. (1956). The theory of prediction. In Modern mathematics for engineers (pp. 165-183). New York: McGraw-Hill.

Williamson, J. (2009). Probabilistic theories of causality. In H. Beebee, Ch. Hitchcock, \& P. Menzies (Eds.), The Oxford Handbook of Causation (pp. 185-212). Oxford University Press.

Woodward, J. (2003). Making things happen: A theory of causal explanation. Oxford University Press. 